\title{
Pengaruh Gaya Kepemimpinan Suportif, Palayanan dan Fasilitas Belajar terhadap Prestasi Belajar Taruna Lalu Lintas Udara Angkatan VIII untuk Mengoptimalkan Daya Serap Lulusan Politeknik Penerbangan Surabaya
}

\author{
Aulia Regia, S.P. ${ }^{1}, B_{a m b a n g}$ Wasito $^{2}$, Sri Lestari ${ }^{3}$,R. Moh. Radix Agustiono ${ }^{4}$ \\ 1),2),3),4)Politeknik Penerbangan Surabaya \\ Jl. Jemur Andayani I/73 Surabaya \\ Email : bamcito@gmail.com
}

\begin{abstract}
This study is entitled "Analysis of the Effect of Supportive Leadership Style, Learning Services and Facilities on Learning Achievement of Air Traffic Youth Class VIII to optimize the Absorption of Graduates at Aviation Polytechnic of Surabaya

Supportive leadership style influences the learning achievement of cadets at Aviation Polytechnic of Surabaya

Services affect the learning achievements of cadets Air Traffic Surabaya Flight Polytechnic.

Learning facilities have an effect on the learning achievements of cadets at Aviation Polytechnic of Surabaya

Air Traffic cadets learning achievements affect the absorption capacity of Surabaya Aviation Polytechnic graduates
\end{abstract}

Key Words : Supportive Leadership Style, Learning Servise dan Facilities, Learning Achievment, Absorption of Graduates

\section{PENDAHULUAN}

Peran pemimpin menjadi tidak kalah pentingnya dalam suatu institusi pendidikan, seorang pemimpin Politeknik Penerbangan yang bijaksana dan baik harus dapat memberikan kepuasan kerja kepada para pegawai maupun para tarunamya dan selalu berusaha memperhatikan semangat kerja mereka. Tentunya pihak pemimpin harus mempunyai kemampuan dalam mengelola, mengarahkan, memerintah dan memotivasi para pegawainya dan para taruna untuk memperoleh tujuan yang diinginkan oleh Politeknik Penerbangan. Pada institusi pendidikan tinggi lebih tepat dipergunakan gaya kepemimpinan supportif dimana Pimpinan sebagai pimpinan tertinggi unit kerja Politeknik melibatkan para wakilnya dalam pengambilan keputusan, jabatan setingkat Ketua Program Studi dan kepala bagian berhak memberikan usulan dalam pengambilan keputusan demikian pula halnya dengan para dosen boleh memberikan usulan melalui ketua program studi dan staf administrasi memberikan usulan melalui kepala bagian terkait.Kepemimpinan suportif juga dikenal dengan istilah perilaku penyokong atau perhatian, dalam gaya ini pemimpin bersedia menjelaskan segala permasalahan pada bawahan, mudah didekati dan memuaskan kinerja.

Menghadapi berbagai tantangan tersebut, Politeknik Penerbangan Surabaya diperlukan adanya penyesuaian dalam menjalankan strategi manajemennya yang selalu berorientasi pada kualitas jasa layanan dan ditunjang sarana serta prasarana yang memadai. Sarana dan prasarana pendidikan perlu adanya pengembangan yang sesuai untuk mendukung progam pendidikan, penelitian dan pengabdian kepada masyarakat. Dari kualitas jasa/layanan ini, diharapkan nantinya para pengelola dapat meningkatkan dan melengkapi kebutuhan secara optimal yang diperlukan pengajaran dan pendidikan, laboratorium, sarana dan prasarana perpustakaan (buku, jurnal, fasilitas elektronik dan sistemnya) untuk tingkat regional, nasional maupun internasional sebagai sumber rujukan yang potensial, akurat, lengkap dan 
baru.

Dalam proses belajar mengajar di Politeknik Penerbangan Surabaya, para taruna akan selalu berharap untuk mendapatkan kualitas jasa layanan pendidikan yang maksimal yang berkaitan dengan proses belajar mengajar termasuk fasilitas perkuliahan dan layanan jasa yang lainnya.

Kegiatan proses belajar mengajar dilaksanakan dengan sarana penunjang yang sangat mendukung, terciptanya kenyamanan adalah kunci utama untuk meningkatkan mutu hasil dan kualitas lulusan.Ruang kelas yang memadai, peralatan praktik yang mendukung, dan metode pembelajaran yang selalu update sesuai dengan kurikulum terbaru di dunia penerbangan semuanya ciptakan agar anak didik mempunyai daya saing dan kompetensi untuk dapat bersaing di dunia kerja, beberapa fasilitas pendukung yang ada Politeknik Penerbangan Surabaya mempunyai 14 Ruang kelas dengan kapasitas kelas 30 orang dan setiap kelas dilengkapi Air Conditioner serta Laptop dan LCD Proyektor dan beberapa diantaranya menggunakan whiteboard magnetic dengan system toutchscreen yang disesuaikan dengan perkembangan teknologi yang sedang berkembang dan sebagai sarana pendukung proses belajar mengajar di kelas. Laboratorium elektronika pendukung yang ada di Politeknik Penerbangan Surabaya guna mengaplikasi dari kajian teori ke dalam praktik maka dalam pelaksanaan praktikum didukung dengan Laboratorium/Workshop Laboratoirum ini berkapasitas 20 orang yang dilengkapi dengan 20 unit Komputer yang terintergrasi untuk praktik bahasa inggris dengan sistem komunikasi 2 arah dan 2 desk operator untuk 2 orang Instruktur Laboratorium komputer yang ada di Akademi Teknik dan Keselamatan Penerbangan Surabaya untuk metode pembelajaran dikemas sedemikian rupa agar anak didik dapat dengan lebih mudah dan lebih interaktif mempelajari setiap komponen yang ada dengan teknik trouble shooting, dengan media modul praktik

\section{Kerangka Konseptual.}

Dari beberapa teori tentang kwalitas dosen, pengalaman dosen, motivasi dan beberapa penelitian terdahulu yang mendukung penelitian ini, maka untuk lebih jelasnya penulis membuat kerangka konseptual Adapun kerangka konsep penelitian sebagai berikut :

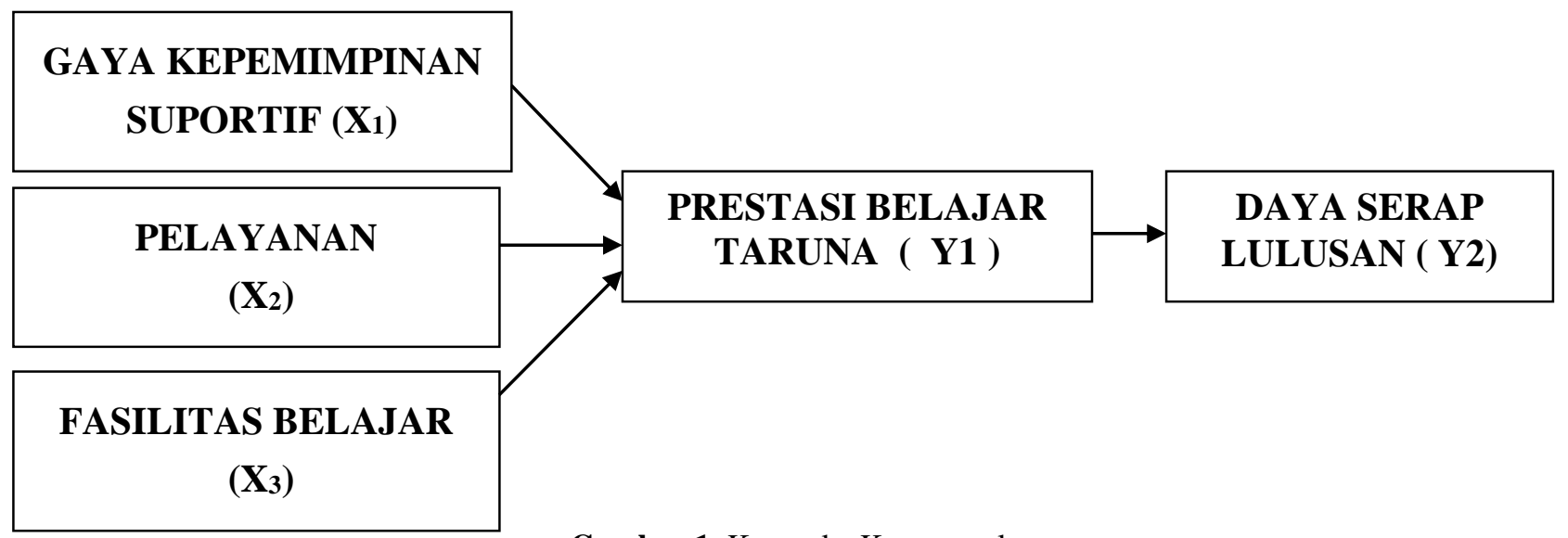

Gambar 1. Kerangka Konseptual 


\section{Hipotesis Penelitian}

Berdasarkan model tersebut, maka hipotesis penelitian yang dirumuskan dan diuji kebenarannya melalui penelitian ini adalah :

1. Bahwa Gaya Kepemimpinan Suportif berpengaruh terhadap Prestasi Belajar Taruna Lalu Lintas Udara Angkatan VIII Politeknik Penerbangan Surabaya.

2. Bahwa Pelayanan berpengaruh terhadap Prestasi Belajar Taruna Lalu Lintas Udara Angkatan VIII Politeknik Penerbangan Surabaya.

3. Bahwa Fasilitas Belajar berpengaruh terhadap Prestasi Belajar Taruna Lalu Lintas Udara Angkatan VIII Politeknik Penerbangan Surabaya.

4. Bahwa Prestasi Belajar Taruna Lalu Lintas Udara Angkatan VIII berpengaruh terhadap Daya Serap Lulusan Politeknik Penerbangan Surabaya.

\section{METODE PENELITIAN}

\section{Definisi Operasional Variabel Penelitian:}

\section{Gaya kepemimpinan Suportif(X1)}

Kepemimpinan yang mendukung ; Memberikan perhatian kepada kebutuhan para bawahan, menciptakan suasana yang bersahabat dalam unit kerja mereka.

Indikator yang digunakan :

1). Memberikan dorongan dan penghargaan bawahan.

2). Membina komunikasi yang baik dan harmonis dengan bawahan.

3). Memberikan hak-hak bawahan.

4). Menunjukkan kepedulian akan kesejahteraan bawahan.

5). Menunjukkan keramahan dan kemampuan untuk melakukan pendekatan personal.

6). Berusaha untuk meningkatkan moral dan semangat stafnya.

\section{Pelayanan(X2)}

Pelayanan adalah suatu aktivitas atau serangkaian aktivitas yang bersifat tidak kasat mata (tidak dapat diraba) yang terjadi akibat adanya interaksi antara taruna dengan Pegawai Politreknik Penerbangan Surabaya untuk memecahkan permasalahan taruna Indikator yang digunakan :

\section{Reliability / keandalan}

Dimensi kualitas jasa yang menjelaskan tentang kemampuan memberikan pelayanan yang dijanjikan dengan segera kepada mahasiswa dengan akurat dan memuaskan. Indikator yang digunakan :

1. = Kesiapan dosen dalam melayani mahasiswa

2. = Kesiapan karyawan dalam melayani mahasiswa

3. = Keakuratan informasi dalam melayani mahasiswa

4. = Administrasi yang tidak berbelit-belit

5. = Ketepatan waktu layanan yang diberikan

\section{Responsiveness / daya tanggap}

Dimensi kualitas jasa yang menjelaskan tentang kemampuan untuk membantu dan tanggap kepada kebutuhan mahasiswa dalam memberikan pelayanan jasa.

Indikator yang digunakan :

6 = Capat tanggap dalam melayanai mahasiswa terhadap permasalahan

7 = Pelayanan dalam memberikan informasi yang akurat

8 = Pelayanan yang komunikatif terhadap kebutuhan mahasiswa

\section{Assurance / jaminan}

Dimensi kualitas jasa yang dinyatakan sebagai persepsi mahasiswa terhadap jaminan 
atau kepastian jasa.

Indikator yang digunakan :

$9=$ Kemampuan dosen dan staf dalam memberikan pelayanan ke mahasiswa

$10=$ Kemampuan karyawan dalam memberikan pelayanan kepada mahasiswa

$11=$ Keramahan dosen dan karyawan dalam memberikan pelayanan

$12=$ Memberikan rasa aman pada mahasiswa

\section{Empathy / perhatian}

Dimensi kualitas jasa yang menjelaskan bagaiana sikap dosen dan karyawan dalam memberikan perhatian kepada para mahasiswa.

Indikator yang digunakan :

13. = Perhatian terhadap saran dan kritik yang diberikan oleh mahasiswa

14. = Kemudahan dalam menemui dosen dan karyawan

15. = Dukungan lembaga atas kebutuhan mahasiswa.

\section{Fasilitas Belajar $\left(\mathbf{X}_{3}\right)$}

Sejumlah kemapuan sarana dan prasaran yang dimiliki oleh sekolah sehingga dapat membantu kelancaran proses belajar mengajar siswa.

Adapun Indikator dari varibel fasilitas belajar $\left(\mathrm{X}_{3}\right)$

1. Fasilitas Gedung yang memadai

2. Fasilitas Poliklinik yang memadai

3. Fasilitas Asrama yang memadai

4. Fasilitas Masjid yang memadai

5. Fasilitas Lapangan Olah Raga yang memadai

6. Fasilitas Kelas yang exclucive dengan Air Conditioner serta Laptop dan LCD Proyektor

7. Modul kuliah yang lengkap

8. Laboratorium yang lengkap

9. Penerangan kampus

10. Iklim lingkungan kampus.

\section{Variabel Prestasi Taruna (Y1)}

Yaitu hasil belajar taruna setelah mengalami proses pengajaran di Akademi. Data tentang hasil Prestasi Belajar Taruna Lalu Lintas Udara berupa Ujian semester yang terdiri dari 10 mata kuliah yaitu :

MK-1 = Kewarganegaraan

MK-2 = Pancasila

MK-3 = Agama

MK-4 = Advace english

MK-5 = Teknologi Informasi ( Programmer )

MK-6 = Pengantar ATC Automation

MK-7 = Cocpit procedure $/$ Flight Simulator

MK-8 = Principle of radar Operation

MK-9 = Etos kerja

MK-10 = Budaya Keselamayan, keamanan dan Pelayanan

\section{Variabel Daya Serap Lulusan (Y2)}

Penerimaan lulusan di dunia kerja sesuai dengan kebutuhan dunia kerja. Berarti lulusan sarjana harus memiliki etos kerja, motivasi yang tinggi, kreatif dan inovatif, serta mampu menyesuaikan keterampilan dan keahliannya sesuai dengan kebutuhan dunia kerja. 
1. Mengetahui kompetensi yang dimiliki harus dimiliki dan yang sesuai dengan kebutuhan reel di perusahaan/ industri.

2. Memiliki pengalaman bekerja secara nyata di suatu perusahaan, industri dan UKM , sehingga soft skills dan hard skills meningkat.

3. Memberikan kesempatan secara langsung untuk dapat terlibat dengan usaha kecil dan menengah untuk mengasah jiwa kewirausahaan mahasiswa.

4. Memiliki kesempatan untuk secara lebih nyata melihat relevansi antara kuliah dan dunia kerja.

5. Memperoleh kesempatan yang lebih besar untuk mendapat bekerja di perusahaan yang bersangkutan atau perusahaan lainnya berkat pengalaman kerja yang dimiliki, atau menciptakan lapangan kerja sebagai wirausahawan/wati.

\section{HASIL PENELITIAN \\ Pengujian Validitas Data}

Pada bab ini penulis akan menguraikan secara lengkap dan terperinci tentang hasil penelitian dan pembahasan dengan menggunakan bantuan pengolahan data dengan SPSS Ver 13 maka dari hasil penghitungan teknik korelasi product moment dihasilkan bahwa semua dari item pertanyaan yang diajukan kepada responden mempunyai korelasi yang tinggi (> $0,50)$ dengan variabel yang bersangkutan. Untuk mengetahui suatu item pernyataan tersebut dinyatakan tingkat validitas atau tingkat keabsahannya jika terdapat korelasi yang signifikan yang ditunjukkan dengan nilai signifikansi yang kurang dari nilai $\alpha=0,05$. Adapun hasil uji validitas adalah sebagai berikut

Tabel 1. Hasil Pengujian Validitas

\begin{tabular}{|l|c|c|c|}
\hline \multicolumn{1}{|c|}{ Variabel } & $\begin{array}{c}\text { Koefisien } \\
\text { Validitas }\end{array}$ & Signifikansi & Keterangan \\
\hline Gaya Kepemimpinan Supportif (X1 ) & 0,973 & 0,000 & Valid \\
\hline Pelayanan (X2) & 0,926 & 0,000 & Valid \\
\hline Fasilitas Belajar (X3) & 0,862 & 0,000 & Valid \\
\hline Daya Serap Lulusan (Y2 ) & 0,907 & 0,000 & Valid \\
\hline
\end{tabular}

Berdasarkan tabel di atas dapat diketahui bahwa seluruh butir item pertanyaan memiliki nilai signifikansi kurang dari 0,05, dengan demikian dapat dikatakan bahwa seluruh butir pertanyaan adalah valid sehingga dapat dilakukan uji reliabilitas.

\section{Pengujian Reliabilitas}

Uji reliabilitas digunakan untuk mengukur suatu kuisioner yang merupakan indikator dari variabel atau konstruk. Suatu kuisioner dikatakan reliabel atau handal jika jawaban seseorang terhadap peryataan adalah konsisten atau stabil dari waktu ke waktu. Suatu konstruk atau variabel dikatakan reliabel jika memberikan nilai cronbach alpha > 0,6 (Nunnally, 1969).

Untuk lebih jelasnya nilai cronbach alpha dapat penulis tampilkan pada tabel berikut :

Tabel 2. Nilai Cronbach's Alpha

\section{Reliability Statistics}

\begin{tabular}{|r|r|}
\hline $\begin{array}{c}\text { Cronbach's } \\
\text { Alpha }\end{array}$ & N of Items \\
\hline .965 & 4 \\
\hline
\end{tabular}


Dari hasil perhitungan olah data dengan bantuan program komputer statistik SPSS ver 12 pada lampiran maka dapat diketahui bahwa nilai cronbach alpha sebesar 0,965 melebihi 0,6 sehingga dapat dikatakan bahwa kusioner pada penelitian ini adalah reliabel atau handal .

\section{Analisis Jalur ( Path Analysis)}

Path analysis digunakan untuk menguji kausalitas yang telah dinyatakan sebelumnya dalam berbagi hubungan sebab akibat melalui model path akan terlihat ada tidaknya kesesuaian model dari hubungan kausalitas yang dibangun dalam model yang di uji. Hubungan antar variabel laten pada penelitian ini terdiri dari :

1. Gaya Kepemimpinan dengan Prestasi Belajar.

2. Pelayanan dengan Prestasi Belajar.

3. Fasilitas belajar dengan Prestasi Belajar.

4. Prestasi Belajar dengan Daya Serap Lulusan

Model structural yang menunjukkan hubungan antar variabel laten dapat dilihat pada gambar 2. di bawah ini:

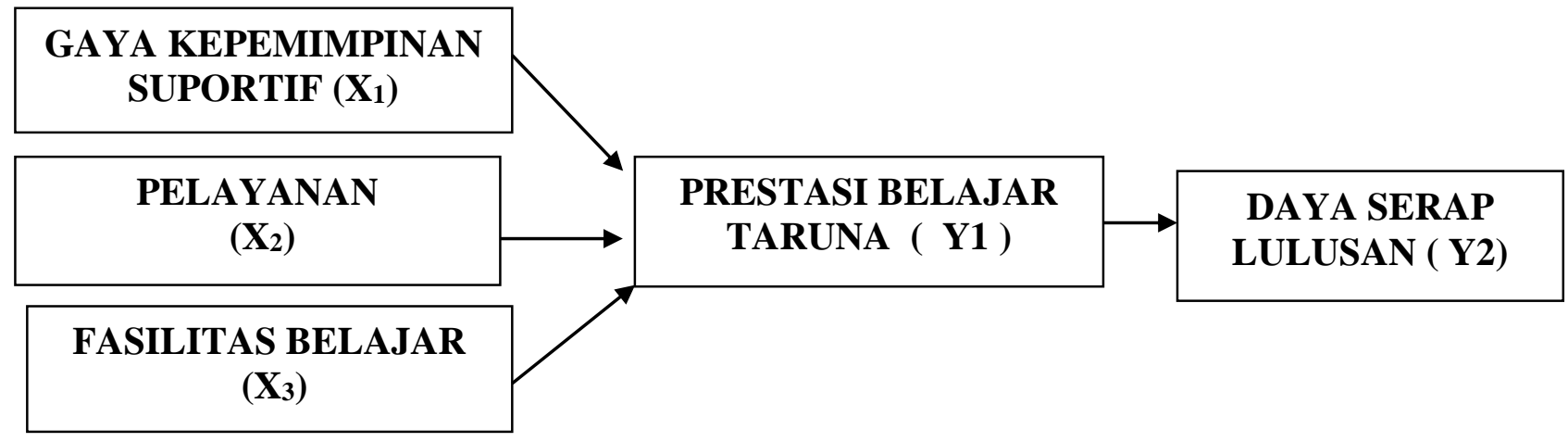

Pengujian Analisa Jalur

Gambar 2. Model Analisis Jalur

Melihat Pengaruh Gaya kepemimpinan Suportif (X1) terhadap Prestasi Belajar (Y1)

$\mathbf{Y} 1=\mathbf{a} 1+\mathbf{b} \mathrm{X} 1+\mathbf{e}$

Untuk melihat pengaruh Gaya kepemimpinan Suportif (X1) terhadap Prestasi Belajar (Y1) dapat dilihat dari perhitungan dalam model summary, khususnya R square di bawah ini:

Tabel 3. Nilai $\mathrm{R}^{2}$ untuk Gaya Kepemimpinan Suportif (X1) dengan Prestasi Belajar (Y1)

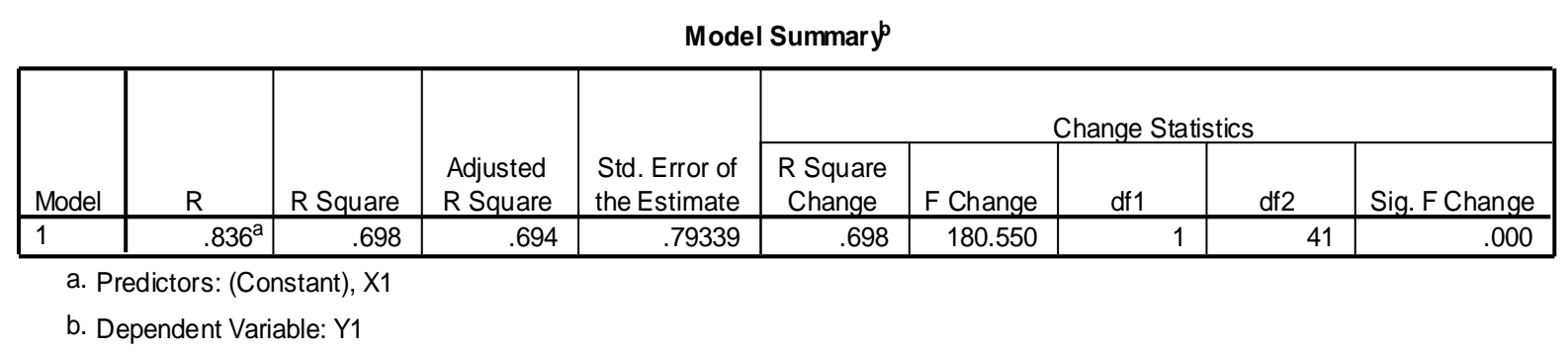

Besarnya R square ( $\mathrm{r}^{2}$ ) adalah 0,698. Angka tersebut digunakan untuk melihat besarnya pengaruh Gaya Kepemimpinan Suportif (X1) terhadap Prestasi Belajar (Y1) dengan cara menghitung Koefisien Determinasi (KD) dengan menggunakan rumus sebagai berikut : $\mathrm{KD}=\mathrm{r}^{2} \times 100 \% \quad \mathrm{KD}=0,698 \times 100 \% \mathrm{KD}=69,8 \%$ Angka tersebut mempunyai maksud bahwa pengaruh Gaya Kepemimpinan Suportif (X1) terhadap Prestasi Belajar (Y1) adalah 69,8 \% sedangkan sisanya 30,2 \% dipengaruhi oleh faktor lain. Dengan kata lain, variabilitas Prestasi Belajar dapat diterangkan dengan menggunakan variabel Gaya Kepemimpinan Suportif sebesar 69,8 \%, sementara pengaruh 
sebesar 30,2 \% disebabkan oleh variabel-variabel lain di luar model ini.

Hubungan antara Gaya Kepemimpinan Suportif dengan Prestasi Belajar Untuk melihat apakah ada hubungan linier antara Gaya Kepemimpinan Suportif (X1) terhadap Prestasi Belajar (Y1), dilakukan langkah-langkah analisis sebagai berikut:

Pertama : menentukan hipotesis

Ho : Tidak ada hubungan linier antara Gaya Kepemimpinan Suportif dengan prestasi Belajar

Ha : Ada hubungan linier antara Gaya kepemimpinan Suportif dengan Prestasi Belajar Kedua : menghitung besarnya angka t penelitian Hasil perhitungan SPSS diperoleh angka t penelitian sebesar $\underline{\mathbf{1 3 , 4 3 7}}$

Tabel 4. Nilai thitung untuk Gaya Kepemimpinan Suportif (X1) dengan Prestasi Belajar (Y1)

Coefficients

\begin{tabular}{|c|c|c|c|c|c|c|c|c|c|}
\hline \multirow{2}{*}{\multicolumn{2}{|c|}{ Model }} & \multicolumn{2}{|c|}{$\begin{array}{l}\text { Unstandardized } \\
\text { Coefficients }\end{array}$} & \multirow{2}{*}{$\begin{array}{c}\begin{array}{c}\text { Standardized } \\
\text { Coefficients }\end{array} \\
\text { Beta }\end{array}$} & \multirow[b]{2}{*}{$t$} & \multirow[b]{2}{*}{ Sig. } & \multicolumn{3}{|c|}{ Correlations } \\
\hline & & B & Std. Error & & & & Zero-order & Partial & Part \\
\hline 1 & (Constant) & 2.854 & .420 & & 6.791 & .000 & & & \\
\hline & $\mathrm{X} 1$ & .700 & .052 & .836 & 13.437 & .000 & .836 & .836 & .836 \\
\hline
\end{tabular}

a. Dependent Variable: $\mathrm{Y} 1$

Ketiga : Menghitung besarnya angka t tabel dengan ketentuan sebagai berikut :

$\alpha=5 \%=0,05$

$\mathrm{df}=\mathrm{n}-2=50-2=48$

$\mathrm{t}_{\text {tabel }(0,05 ; 48)}=1,6772$

Keempat : menentukan criteria

Jika t penelitian > t tabel maka Ho ditolak dan Ha diterima

Jika t penelitian < t tabel maka Ho ditolak dan Ha diterima

Kelima : membuat Keputusan

Didasarkan hasil penghitungan, diperoleh angka t penelitian sebesar 13,437 > dari t tabel sebesar 1,6772. Sehingga H0 di tolak dan Ha diterima. Artinya ada hubungan linier antara Gaya Kepemimpinan Suportif dengan Prestasi Belajar Taruna. Besarnya pengaruh Gaya Kepemimpinan Suportif terhadap Prestasi Belajar Taruna sebesar 0,836 atau $\underline{\mathbf{8 3}, 6 \%}$

Melihat Pengaruh Pelayanan (X2) terhadap Prestasi Belajar (Y1)

$\mathrm{Y} 1=\mathbf{a} 2+\mathrm{b} \mathrm{X} 2+\mathrm{e}$

Untuk melihat pengaruh pelayanan (X2) terhadap Prestasi Belajar (Y1) dapat dilihat dari perhitungan dalam model summary, khususnya R square di bawah ini:

Tabel 5. Nilai $\mathrm{R}^{2}$ untuk Pelayanan (X2) dengan Prestasi Belajar (Y1)

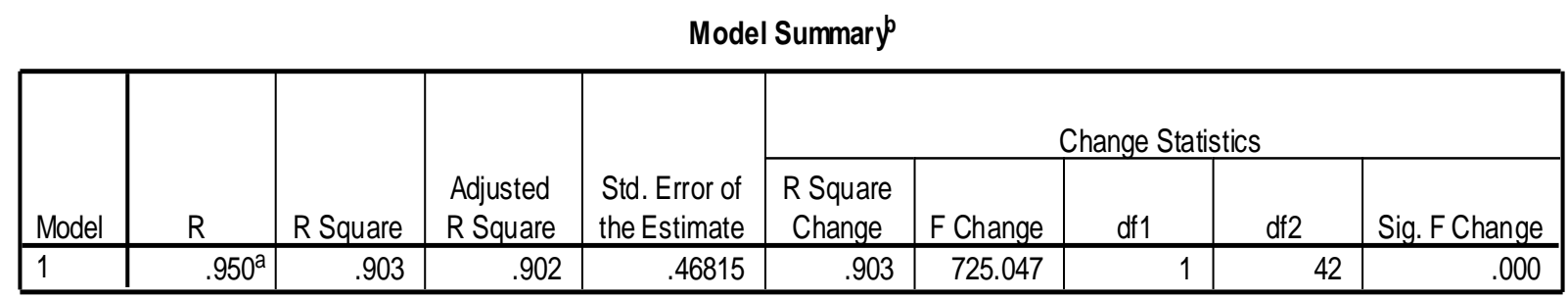

a. Predictors: (Constant), X2

b. Dependent Variable: Y1

Besarnya $\mathrm{R}$ square ( $\mathrm{r}^{2}$ ) adalah 0,903. Angka tersebut digunakan untuk melihat 
besarnya pengaruh Pelayanan (X2) terhadap Prestasi Belajar (Y1) dengan cara menghitung Koefisien Determinasi (KD) dengan menggunakan rumus sebagai berikut:

$\mathrm{KD}=\mathrm{r}^{2} \times 100 \%$

$\mathrm{KD}=0,903 \times 100 \%$

$\mathrm{KD}=90,3 \%$

Angka tersebut mempunyai maksud bahwa pengaruh pelayanan (X2) terhadap Prestasi Belajar (Y1) adalah 90,3\% sedangkan sisanya 9,7\% dipengaruhi oleh faktor lain. Dengan kata lain, variabilitas Prestasi Belajar dapat diterangkan dengan menggunakan variabel Pelayanan sebesar 90,3 \%, sementara pengaruh sebesar 9,7\% disebabkan oleh variabelvariabel lain di luar model ini.

Hubungan antara Pelayanan dengan Prestasi Belajar

Untuk melihat apakah ada hubungan linier antara Pelayanan

Belajar (Y1), dilakukan langkah-langkah analisis sebagai berikut:

(X2) terhadap Prestasi

Pertama : menentukan hipotesis

Ho : Tidak ada hubungan linier antara Pelayanan dengan prestasi Belajar

Ha : Ada hubungan linier antara pelayanan dengan Prestasi Belajar

Kedua : menghitung besarnya angka t penelitian

Hasil perhitungan SPSS diperoleh angka t penelitian sebesar $\underline{\mathbf{2 6 , 9 2 7}}$

Tabel 6. Nilai t hitung untuk pelayanan (X2) dengan Prestasi Belajar (Y1)

Coefficients ${ }^{\mathrm{a}}$

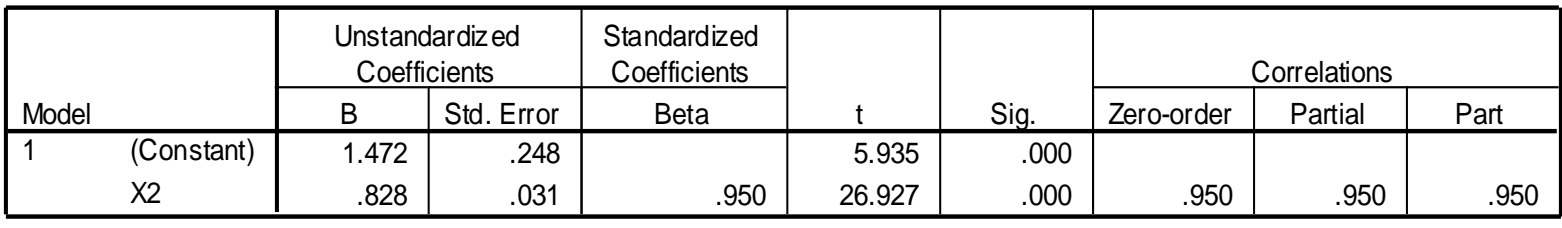

a. Dependent Variable: Y1

Ketiga : Menghitung besarnya angka t tabel dengan ketentuan sebagai berikut :

$\alpha=5 \%=0,05$

$\mathrm{df}=\mathrm{n}-2=50-2=48$

$\mathrm{t}$ tabel $(0,05 ; 48)=1,6772$

Keempat : menentukan criteria

Jika $t$ penelitian $>\mathrm{t}$ tabel maka Ho ditolak dan Ha diterima

Jika $t$ penelitian $<\mathrm{t}$ tabel maka Ho ditolak dan Ha diterima

Kelima : membuat Keputusan

Didasarkan hasil penghitungan, diperoleh angka $t$ penelitian sebesar 26,927 > dari t tabel sebesar 1,6772. Sehingga H0 di tolak dan Ha diterima. Artinya ada hubungan linier antara Pelayanan dengan Prestasi Belajar Taruna. Besarnya pengaruh pelayanan terhadap Prestasi Belajar Taruna sebesar 0,950 atau $95 \%$

\section{Melihat Fasilitas Belajar (X3) terhadap Prestasi Belajar (Y1)}

$$
\mathbf{Y} 1=\mathbf{a}+\mathbf{b} \mathbf{X} 3+\mathbf{e}
$$

Untuk melihat pengaruh Fasilitas Belajar (X3) terhadap Prestasi Belajar (Y1) dapat dilihat dari perhitungan dalam model summary, khususnya R square di bawah ini: 
Tebel 7. Nilai $\mathrm{R}^{2}$ untuk Fasilitas Belajar (X3) dengan Prestasi Belajar (Y1)

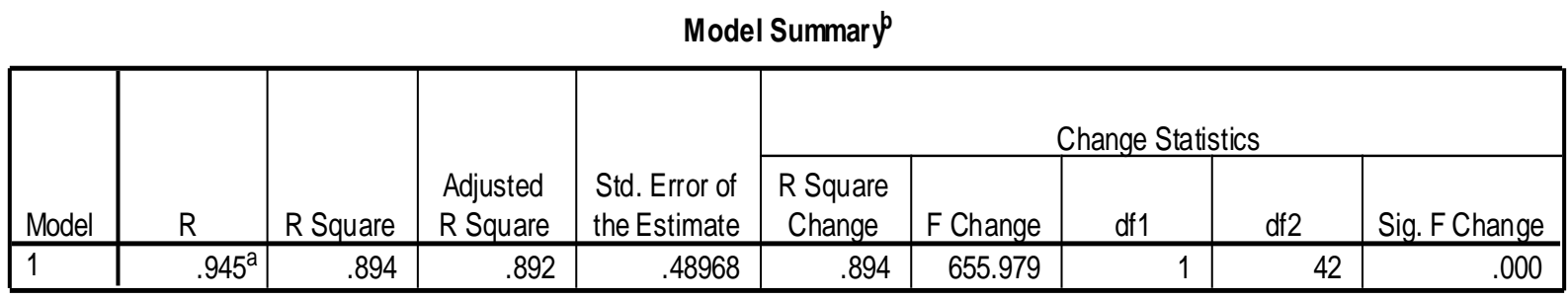

a. Predictors: (Constant), X3

b. Dependent Variable: Y1

Besarnya $\mathrm{R}$ square ( $\mathrm{r}^{2}$ ) adalah 0,894 . Angka tersebut digunakan untuk melihat besarnya pengaruh Fasilitas Belajar (X3) terhadap Prestasi Belajar (Y1) dengan cara menghitung Koefisien Determinasi (KD) dengan menggunakan rumus sebagai berikut:

$\mathrm{KD}=\mathrm{r}^{2} \times 100 \%$

$\mathrm{KD}=0,894 \times 100 \%$

$\mathrm{KD}=89,4 \%$

Angka tersebut mempunyai maksud bahwa pengaruh Fasilitas Belajar (X3) terhadap Prestasi Belajar (Y1) adalah 89,4\% sedangkan sisanya 10,6\% dipengaruhi oleh faktor lain. Dengan kata lain, variabilitas Prestasi Belajar dapat diterangkan dengan menggunakan variabel Fasilitas Belajar sebesar 89,4 \%, sementara pengaruh sebesar 10,6 \% disebabkan oleh variabel-variabel lain di luar model ini.

\section{Hubungan antara Fasilitas Belajar dengan Prestasi Belajar}

Untuk melihat apakah ada hubungan linier antara Fasilitas Belajar (X3) terhadap Prestasi

Belajar (Y1), dilakukan langkah-langkah analisis sebagai berikut:

Pertama : menentukan hipotesis

Ho : Tidak ada hubungan linier antara Fasilitas Belajar dengan prestasi Belajar

Ha : Ada hubungan linier antara Fasilitas Belajar dengan Prestasi Belajar

Kedua : menghitung besarnya angka t penelitian

Hasil perhitungan SPSS diperoleh angka t penelitian sebesar $\underline{\mathbf{2 5 , 6 1 2}}$

Tabel 8. Nilai t hitung untuk Fasilitas Belajar (X3) dengan Prestasi Belajar (Y1)

Coefficients

\begin{tabular}{|c|c|c|c|c|c|c|c|c|c|}
\hline \multirow{2}{*}{\multicolumn{2}{|c|}{ Model }} & \multicolumn{2}{|c|}{$\begin{array}{l}\text { Unstandardized } \\
\text { Coefficients }\end{array}$} & $\begin{array}{l}\text { Standardized } \\
\text { Coefficients }\end{array}$ & \multirow[b]{2}{*}{ t } & \multirow[b]{2}{*}{ Sig. } & \multicolumn{3}{|c|}{ Correlations } \\
\hline & & B & Std. Error & Beta & & & Zero-order & Partial & Part \\
\hline & (Constant) & .233 & .326 & & 5.356 & .001 & & & \\
\hline & X3 & .983 & .038 & .945 & 25.612 & .000 & .945 & .945 & .945 \\
\hline
\end{tabular}

a. Dependent Variable: $Y 1$

Ketiga : Menghitung besarnya angka t tabel dengan ketentuan sebagai berikut :

$\alpha=5 \%=0,05$

$\mathrm{df}=\mathrm{n}-2=50-2=48$

$\mathrm{t}_{\text {tabel }(0,05 ; 48)}=1,6772$

Keempat : menentukan criteria

Jika $t$ penelitian $>t$ tabel maka Ho ditolak dan Ha diterima

Jika t penelitian < t tabel maka Ho ditolak dan Ha diterima

Kelima : membuat Keputusan

Didasarkan hasil penghitungan, diperoleh angka t penelitian sebesar 25,612 > dari t tabel sebesar 1,6772. Sehingga H0 di tolak dan Ha diterima. Artinya ada hubungan linier antara Fasilitas Belajar dengan Prestasi Belajar Taruna. Besarnya pengaruh Fasilitas 


\section{terhadap Prestasi Belajar Taruna sebesar 0,945 atau 94,5\%}

\section{Melihat Prestasi Belajar (Y1) terhadap Daya Serap Lulusan (Y2)}

$\mathbf{Y} 1=\mathbf{a}+\mathbf{b} \mathbf{X 3}+\mathbf{e}$

Untuk melihat pengaruh Prestasi Belajar (Y1) terhadap Daya Serap Lulusan (Y2) dapat dilihat dari perhitungan dalam model summary, khususnya $\mathrm{R}$ square di bawah ini:

Tabel 9. Nilai $\mathrm{R}^{2}$ untuk Prestasi Belajar (Y1) dengan Daya Serap Lulusan (Y2)

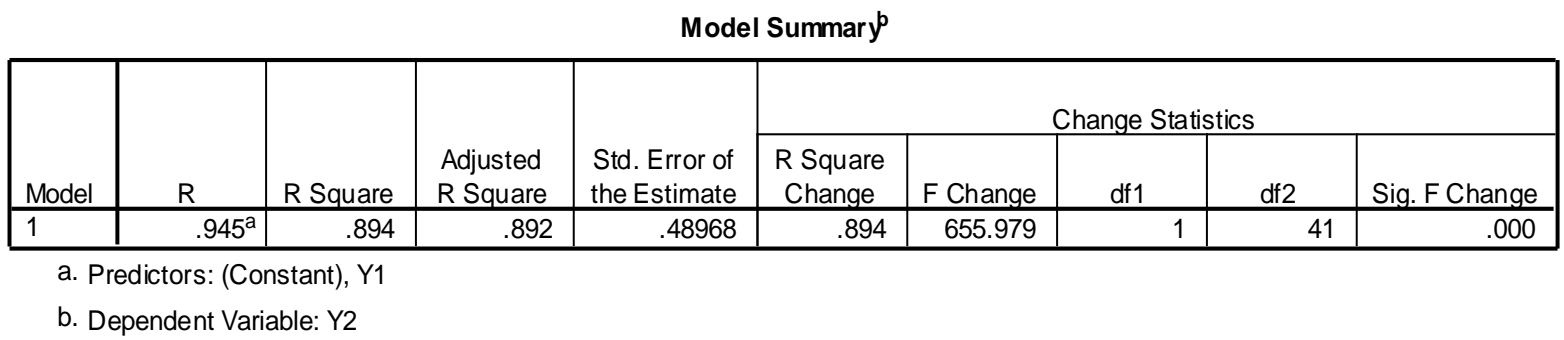

Besarnya $\mathrm{R}$ square ( $\mathrm{r}^{2}$ ) adalah 0,910. Angka tersebut digunakan untuk melihat besarnya pengaruh Prestasi Belajar (Y1) terhadap Daya Serap Lulusan (Y2) dengan cara menghitung Koefisien Determinasi (KD) dengan menggunakan rumus sebagai berikut:

$\mathrm{KD}=\mathrm{r}^{2} \times 100 \%$

$\mathrm{KD}=0,910 \times 100 \%$

$\mathrm{KD}=91 \%$

Angka tersebut mempunyai maksud bahwa pengaruh Prestasi Belajar (Y1) terhadap Daya Serap Lulusan (Y2) adalah $91 \%$ sedangkan sisanya $9 \%$ dipengaruhi oleh faktor lain. Dengan kata lain, variabilitas daya serap Lulusan dapat diterangkan dengan menggunakan variabel Prestasi Belajar sebesar $91 \%$, sementara pengaruh sebesar $1 \%$ disebabkan oleh variabel-variabel lain di luar model ini.

Hubungan antara Prestasi Belajar (Y1) dengan Daya Serap Lulusan (Y2) tuk melihat apakah ada hubungan linier antara Prestasi Belajar (Y1) terhadap Daya Serap Lulusan (Y2), dilakukan langkah-langkah analisis sebagai berikut:

Pertama : menentukan hipotesis

Ho : Tidak ada hubungan linier antara Fasilitas Belajar dengan prestasi Belajar

Ha : Ada hubungan linier antara Fasilitas Belajar dengan Prestasi Belajar

Kedua : menghitung besarnya angka t penelitian

Hasil perhitungan SPSS diperoleh angka t penelitian sebesar $\underline{\mathbf{3 6 , 3 7 6}}$

Tabel 10. Nilai thitung untuk Prestasi Belajar (Y1) dengan Daya Serap Lulusan (Y2)

Coefficients $^{\mathrm{a}}$

\begin{tabular}{|c|c|c|c|c|c|c|c|c|c|}
\hline \multirow{2}{*}{\multicolumn{2}{|c|}{ Model }} & \multicolumn{2}{|c|}{$\begin{array}{l}\text { Unstandardized } \\
\text { Coefficients }\end{array}$} & \multirow{2}{*}{$\begin{array}{c}\begin{array}{c}\text { Standardized } \\
\text { Coefficients }\end{array} \\
\text { Beta } \\
\end{array}$} & \multirow[b]{2}{*}{$t$} & \multirow[b]{2}{*}{ Sig. } & \multicolumn{3}{|c|}{ Correlations } \\
\hline & & B & Std. Error & & & & Zero-order & Partial & Part \\
\hline & (Constant) & 1.618 & .625 & & 6.288 & .000 & & & \\
\hline & Y1 & .934 & .009 & .954 & 36.376 & .000 & .954 & .954 & .954 \\
\hline
\end{tabular}

a. Dependent Variable: Y2

Ketiga : Menghitung besarnya angka t tabel dengan ketentuan sebagai berikut :

$\alpha=5 \%=0,05$

$\mathrm{df}=\mathrm{n}-2=50-2=48$

$\mathrm{t}$ tabel $(0,05 ; 48)=1,6772$

Keempat : menentukan criteria

Jika $t$ penelitian $>t$ tabel maka Ho ditolak dan Ha diterima 
Jika t penelitian < t tabel maka Ho ditolak dan Ha diterima

Kelima : membuat Keputusan

Didasarkan hasil penghitungan, diperoleh angka t penelitian sebesar 36,376>dari t tabel sebesar 1,6772. Sehingga H0 di tolak dan Ha diterima. Artinya ada hubungan linier antara Prestasi Belajar (Y1) dengan Daya Serap Lulusan (Y2) Besarnya pengaruh Prestasi belajar terhadap Daya Serap Lulusan Taruna sebesar 0,954 atau 95,4 \%

\section{KESIMPULAN}

Dari hasil penelitian ini maka dapat disimpulkan bahwa :

1. Bahwa gaya kepemimpinan supportif berpengaruh terhadap prestasi belajar taruna Lalu Lintas Udara Politeknik Penerbangan Surabaya.

2. Bahwa pelayanan berpengaruh terhadap prestasi belajar taruna Lalu Lintas Udara Politeknik Penerbangan Surabaya.

3. Bahwa fasilitas belajar berpengaruh terhadap prestasi belajar taruna Lalu Lintas Udara Politeknik Penerbangan Surabaya.

4. Bahwa prestasi belajar taruna Lalu Lintas Udara berpengaruh terhadap daya serap lulusan Politeknik Penerbangan Surabaya.

\section{DAFTAR PUSTAKA}

Amstrong, Michael, 2016, Manajemen Sumber Daya Manusia, PT.Eltex Media Computindo, Jakarta.

Anang, 2015.Tesis.Pengaruh Gaya Kepemimpinan partisipatif dan gaya kepemimpinan kharismatik terhadap kinerja pegawai Pemda Sidoarjo.

Arikunto, Suharsimi, 2016Prosedur Penelitian; Suatu Pendekatan Praktek, cetakan kesebelas . Rineka Cipta, Jakarta.

Dajan, Anto .2015. Pengantar Metode Statistik II, Jakarta : Penerbit LP3ES.

Djiwanto, Gunawan,2013, Manajemen Sumber Daya manusia, Penerbit Andi Offset, Yogyakarta.

Fred E Fildler, dan Martin M Chemers. 2012. Leadership and effective Management. Glenvief Inc

Gasperz, Vincent. 2012. Manajemen Kualitas dalam Industri Jasa, Cetakan kedua, PT Gramedia Pustaka Utama, Jakarta

Ghiselli, Edwin. 2016, Leadership, Pasific palisades, California.

Handoko Hani.T 2015,ManajemenPersonalia dan Sumberdaya Manusia BPFE Yogyakarta Hasibuan, Melayu SP, 2015, Manajemen Sumber Daya Manusia, Haji Masagung, Jakarta. Idham, 2012.Tesis.Pengaruh Gaya Kepemimpinan Suportif dan gaya kepemimpinan fasilitatif terhadap prestasi kerja pegawai Kecamatan Tanggulangin Sidoarjo.

Idrus, 2012.Tesis.Pengaruh gaya kepemimpinan Struktural, suportif dan Kharismatik terhadap prestasi kerja pegawai kecamatan Buduran Sidoarjo.

Kuna, Winaya, 2013. Manajemen Sumber Daya Manusia, Bali. Penerbit Fakultas Ekonomi Udayana Denpasa

Moenir, 2012.Manajemen Pelayanan Umum di Indonesia. Penerbit Bumi Aksara. Jakarta.

Nawawi, Handari. 2014. Kepemimpinan yang efektif. Yogyakarta; Penerbit UGM.

Tjiptono, Fandi. 2016. Manajemen Jasa. Penerbit Andi. Yogyakarta.

Suprapto, J. 2015. Pengukuran Tingkat Kepuasan Pelanggan Untuk Menaikkan Pangsa Pasar. Rineka Cipta. Jakarta.

Siagian, Sondang P. 2014. Teori dan Praktek Kepemimpinan. Jakarta: Penerbit Rineka Cipta, 